\title{
Przymierza Izraelitów z narodami w świetle zakazów Pięcioksięgu Biblii greckiej
}

\section{Wstęp}

W drugiej części proponowanej analizy greckich tekstów Starego Testamentu ${ }^{2}$ należy zauważyć istotną różnicę między zapisami prawa Mojżeszowego, podanego w Wj 23,32; 34,12; Pwt 7,2 oraz Sdz 2,2, a przypadkami podanymi poniżej. Jak się bowiem okazało, zakaz przymierzy w Księgach Wyjścia i Powtórzonego Prawa dotyczył ściśle narodów zamieszkujących wprost tereny przeznaczone dla narodu wybranego, co potwierdza również kazus Gabaonitów. Poniższe przykłady omawiają przypadki umów między nacjami sąsiadującymi z Izraelem a Abrahamem, później zaś władcami królestwa północnego lub południowego. W krajach tych Izraelici jednak nie zamieszkiwali. Można więc sądzić, że nie naruszają one zakazu podanego przez Mojżesza. Jak jednak oceniają je hagiografowie? Przykładów takich traktatów, zawierających najważniejszy termin grecki diathēke, Stary Testament dostarcza kilka. Wszystkie one zostaną więc zaczerpnięte z Septuaginty, by trzymać się jednolitej wersji tekstów biblijnych i w konsekwencji spróbować odpowiedzieć na ostateczne pytanie: czy zawierając układ z Rzymem (8,17-32), Juda Machabeusz, jako dowódca powstania machabejskiego, złamał zakaz Mojżeszowy, czy nie? Stanie się to tematem trzeciej części tryptyku egzegetycznego, w którą obecne omówienie wprowadzi ${ }^{3}$.

\footnotetext{
${ }^{1}$ Ksiądz Janusz Nawrot, prof. dr hab. — ur. w 1960 roku w Międzychodzie, woj. wielkopolskie; kapłan archidiecezji poznańskiej od 1985 roku; wykładowca WT UAM w Poznaniu; pracownik Zakładu Teologii Historycznej; specjalizuje się w egzegezie i teologii Starego Testamentu; e-mail: jannaw@amu.edu.pl. ORCID: 0000-0002-2498-5081.

${ }^{2}$ Por. J. Nawrot, Izrael wobec zakazu sprzymierzania się z poganami w wybranych tekstach Septuaginty: częśś I, „Poznańskie Studia Teologiczne” 34 (2019), s. 7-28.

${ }^{3}$ Prezentowany artykuł jest II częścią większej całości, którą zakończy część III. Jej celem będzie próba odpowiedzi na postawione wyżej pytania.
} 
Jakie są konkretne przykłady paktów z sąsiadami? Poniższe fragmenty zawierają potrzebne o nich wiadomości.

\section{1) przymierze Abrahama z Abimelekiem}

Wydawać by się mogło, że przymierze patriarchy Izraela z Abimelekiem nie powinno wejść w zakres tematu niniejszego artykułu, ponieważ dokonało się na kilka wieków przed nastaniem reguł danych przez Boga Mojżeszowi. Tymczasem $\mathrm{z}$ teologicznego punktu widzenia Abraham, jako przodek narodu wybranego, nie znając prawa, już postępował zgodnie z nim, czego ewidentnym przykładem jest nakaz wyszukania żony dla Izaaka (Rdz 24,3-4) w myśl późniejszego zapisu Wj 34,164. Nie sposób nawet pomyśleć, że w kwestii tak ważnej jak zakaz wchodzenia w przymierza z poganami patriarcha narodu mógłby działać w sposób sprzeczny z prawem, później ogłoszonym jako norma postępowania całego ludu, potomków Abrahama. Nie trzeba przypominać, że ów prawdopodobnie historyczny pakt został przedstawiony w Biblii w sposób teologiczny, przez autora będącego członkiem wspólnoty wiary, której Abraham był znamienitym przodkiem. Stosowny zapis znajduje się w tekście Rdz 21,27, co powtarza później jeszcze w. $32^{5}$ :

$i$ wzią Abraham owce $i$ woty, i dat Abimelekowi,

i obaj ustanowili przymierze.

Werset stanowi część większej jednostki tekstowej w. 22-34 relacjonującej zawarcie przymierza między obiema stronami, choć raczej nie można uznać całego opowiadania za historyczne, lecz etiologiczne, nawiązujące do związków głównego bohatera z Beer-Szebą̨ . Na strukturę literacką składają się następujące części:

a) żądanie króla Geraru wobec Abrahama (w. 22-23),

\footnotetext{
${ }^{4}$ Podobnie teologiczną wymowę przyjmuje ofiara Noego po potopie, całkowicie zgodnie z przepisami późniejszego prawa w Kpł 11,2-22; 20,25; 22,22; Pwt 14,3-20 identyfikującego pozwolenie spożywania zwierząt czystych z możliwością składania ich w ofierze (m.in. Wj 12,5; 29,1; Kpł 1,3.10; Lb 29,13-30; Ez 45,23), por. J.H. Sailhamer, The Meaning of the Pentateuch: Revelation, Composition and Interpretation, Downers Grove 2009, s. 592; V.P. Hamilton, The Book of Genesis, Chapters 1-17, NICOT, Grand Rapids 1990, s. 307-308; B.N. Peterson, Genesis as Torah: Reading Narrative as Legal Instruction, Eugene 2018, s. 68-69.

${ }^{5} \mathrm{O}$ ile nie zostało podane inaczej, wszystkie tłumaczenia są thumaczeniami własnymi tekstu greckiego.

${ }^{6}$ Por. G.W. Coats, Genesis: with an Introduction to Narrative Literature, FOTL 1, Grand Rapids 1983, s. 157.
} 
b) odpowiedź Abrahama (w. 24),

c) wyrzut Abrahama wobec Abimeleka i odpowiedź króla (w. 25-26),

d) zawarcie przymierza (w. 27),

e) rytuał etiologiczny nazwy Beer-Szeba (w. 28-31),

f) rozejście się obu stron przymierza (w. 32) ${ }^{7}$.

Główny w. 27 jest zarówno odpowiedzią Abrahama na żądanie Abimeleka złożenia przysięgi na wierność i uczciwość wobec jego rodu i kraju, jak i skutkiem sprzeczki o studnię dla bydła, którą słudzy króla siłą odebrali pasterzom Abrahama, o czym król nie wiedział (w. 25-26). Podarunek w postaci zwierząt należących do patriarchy jest z kolei odpowiedzią na wcześniejszy, podobny dar Abimeleka $(20,14 a)$ oraz świadectwem ważności zawieranego obecnie przymierza.

Przykład w Rdz 24,3-4, że Abraham, żyjąc w swoim czasie, stosował się do praw podanych explicite dopiero przez Mojżesza, wychodzi naprzeciw obiekcji J. Lemańskiego, który w swoim komentarzu zanotował: „Inna sprawa, że patriarcha zawierając traktat z obcymi (Kananejczycy?) wykazuje się nieznajomością późniejszych przepisów Prawa Mojżeszowego (Wj 23,33; Pwt 7,2; Kpł 20,26)"». Gdyby rozpatrywać omawiane przymierze z punktu widzenia historii, można by z powodzeniem taką tezę przyjąć, gdyż Abraham żył kilka wieków wcześniej niż Mojżesz. Natomiast jeśli jest to tylko narracja etiologiczna, zdecydowanie na pierwsze miejsce wychodzi teologia całego passusu, nie jego ewentualna historia, choć niewątpliwie całe opowiadanie jest umocowane historycznie w zwyczajach wówczas panujących, na czym hagiografowi mocno zależało. Do tego samego typu zachowań wyrażających wierność Bogu na wzór Mojżesza należy zapewne także wzywanie imienia Pana, co czynili zarówno Abraham (Rdz 12,8; 13,4; 21,33), jak i później Mojżesz (Wj 34,5), budowanie przez obu ołtarza ku czci Pana (Rdz 12,7-8; 13,18; 22,9 oraz Wj 17,15; 20,25; 24,4), złożenie ofiary ze zwierząt uznanych przez prawo za rytualnie czyste $(\operatorname{Rdz} 15,9$ i Kpł 1,10; 5,15-16; Pwt 21,3-9), gościna dana Bogu z najprzedniejszych składników, przeznaczonych później wręcz jako ofiara dla Pana (Rdz 18,6 i Wj 12,39; Kpł 2,1-5), wreszcie jagnię na ofiarę (Rdz 22,7-8 i Kpł 5,7; 12,8). Takie zestawienie uzasadnia tezę, że Abraham został przedstawiony teologicznie jako sługa bezwzględnie wierny Bogu także w tym, co czynił, chociaż z historycznego

\footnotetext{
${ }^{7}$ Problemy związane z koncentryczną budową całego passusu por. H. Krauss, M. Küchler, Erzählungen der Bibel II: Das Buch Genesis in literarischer Perspektive. Abraham - Isaak - Jakob, Göttingen 2004, s. 93 oraz J. Cazeaux, Le partage de minuit. Essai sur la Genèse, LD, Paris 2006, s. 345-350.

${ }^{8}$ Por. J. Lemański, Księga Rodzaju, rozdziały 11,27-36,43. Wstęp - przektad z oryginatu komentarz, NKB.ST, t. I/2, Częstochowa 2014, s. 466-467.

${ }^{9}$ Powyższe przykłady wyliczono w obu przypadkach na fundamencie zbieżności terminologicznej.
} 
punktu widzenia nie miał możności poznania przepisów, którymi jego potomkowie będą żyć według postanowień prawa Mojżeszowego. Stąd nie potrzeba stosować przepisów prawa o przymierzach jako teologicznego tła dla relacji Abrahama z Abimelekiem, ponieważ nie chodziło o przymierze o charakterze religijnym, lecz wyłącznie świeckim czy - jak nazywają go niektórzy egzegeci - o „traktat o przyjaźni” ${ }^{10}$. W tym przypadku wiara Abrahama nie została w niczym zagrożona.

\section{2) przymierze Salomona z Chiramem}

Zawarcie takiego przymierza można odnaleźć w wersecie 3 Bas $5,26^{11}$ :

Pan dat madrość Salomonowi wedtug tego, co mu zapowiedzial

i trwat pokój między Chiramem i między Salomonem

a między sobq ustanowili przymierze

Ów bardzo pozytywny w swej wymowie tekst stanowi zakończenie bliższego kontekstu w. 15-26 relacjonujących polityczno-ekonomiczne koneksje Salomona z Chiramem, królem Tyru, przypieczętowane traktatem. Pisany w stylu deuteronomistycznym ukazuje ówczesne relacje handlowe między niezależnymi od siebie państwami. Jeden cel porządkuje całość tych relacji, mianowicie budowa świątyni ku czci Boga przez syna Dawida (w. 17-19). Struktura literacka całego passusu jest dość prosta:

a) wprowadzenie (w. 15),

b) opis wymiany not dyplomatycznych (w. 16-20),

c) uznanie króla Tyru dla mądrości króla Izraela (w. 21$)^{12}$,

d) sformułowanie oczekiwań drugiej strony paktu (w. 22-23),

e) wymiana handlowa między oboma królestwami (w. 24-25).

Sam w. 26 dzieli się ściśle na dwie całkowicie różne części: część teologiczna akcentuje mądrość jako specjalny dar od Pana dla Salomona (w. 26a), część hi-

${ }^{10}$ Z politycznego punktu widzenia por. R.N. Whybray, Genesis [w:] The Oxford Bible Commentary, ed. by J. Barton, J. Muddiman, Oxford 2001, s. 53; J. Lemański, Księga Rodzaju..., s. 473.

11 Przyjęte w artykule oznaczenia nazw greckich ksiąg biblijnych pisanych italikiem są następujące: $1 \mathrm{Bas}=1 \mathrm{Sm} ; 2 \mathrm{Bas}=2 \mathrm{Sm}, 3 \mathrm{Bas}=1 \mathrm{Krl}, 4 \mathrm{Bas}=2 \mathrm{Krl}, 1 \mathrm{Par}=1 \mathrm{Krn}, 2 \mathrm{Par}=2 \mathrm{Krn}$, $2 E z d=\operatorname{Ezd}(2$ Ezd 1-10) $+\mathrm{Ne}(2$ Ezd 11-20), Ps = Księga Psalmów z numeracją w Septuagincie, Ier $=$ Księga Jeremiasza $\mathrm{z}$ jej podziałem w Septuagincie.

12 Głoszenie uznania dla Boga Izraela przez pogańskiego króla nosi wyraźne znamię stylu deuteronomistycznego, na podobieństwo wypowiedzi Jetry, teścia Mojżesza do swego zięcia w Wj 18,10. Natomiast chwalenie bóstw partnerów politycznych należało do ówczesnego stylu dyplomacji, por. M.A. Sweeney, I \& II Kings: A Commentary, OTL, Louisville 2013, s. 103. 
storyczna zaś prezentuje zawarcie formalnego traktatu handlowego między oboma władcami i ich krajami (w. 26b) ${ }^{13}$.

Jak widać, uzgodnienie obu władców ma charakter umowy między dwoma równymi sobie stronami, przy czym ekonomiczny fundament porozumienia został ukazany jako przymierze o charakterze pokojowym, zgodnie z symboliką imienia Salomona, jako wyraz jego przezorności w relacjach międzynarodowych ${ }^{14}$. Warto zauważyć całkowity brak odniesienia religijnego w stosunkach między oboma królami, a każdy z nich pozostaje przy swojej wierze. Traktat nie wchodzi zatem w obszar zastrzeżony przez zakaz prawa Mojżeszowego. $Z$ tej racji wydaje się zrozumiałe dopuszczenie obcej ludności do udziału w stawianiu domu Bożego, co zostaje wręcz pochwalone przez autora jako dowód mądrości króla ${ }^{15}$.

\section{3) przymierze Asy z Ben-Hadadem I}

Odnaleźć je można w zapisie 3 Bas 15,19, niemal identycznie powtórzonym w 2 Par 16,3:

Zawrzyj przymierze między mna i toba, między ojcem moim i ojcem twoim

Spójrz! Posyłam ci dary srebra i złota!

Szybko zerwij twoje przymierze z Baszq, królem Izraela, a odstapi ode mnie.

Werset znajduje się w bliższym, literackim kontekście w. 16-21, relacjonującym stan konfliktu zbrojnego między judzkim królem, Asą, a władcą izraelskim, Baszą, jako schedy po walkach między poprzednikami obu władców na tronie królestwa południowego i północnego: Abiaszem i Jeroboamem I. Struktura passusu jest bardzo przejrzysta:

a) informacja wprowadzająca o permanentnym stanie wojny między królem Izraela i Judy, przy czym król Izraela był górą w tym konflikcie (w. 16-17) ${ }^{16}$;

${ }_{13}$ Por. V. Fritz, 1 \& 2 Kings: A Continental Commentary, Minneapolis 2003, s. 60.

${ }_{14}$ Por. P.R. House, 1,2 Kings: An Exegetical and Theological Exposition of Holy Scripture, NAC 8, Nashville 1995, s. 124.

${ }_{15}$ Przeciwnie do Ezd 4,2-3, gdy przy odbudowie II świątyni odrzucono propozycję współpracy, por. J.B. Łach, Księgi 1-2 Królów. Wstęp - przekład z oryginału - komentarz - ekskursy [w:] Pismo Święte Starego Testamentu, t. 4, cz. 2, Poznań 2007, s. 183.

${ }^{16}$ Czas nastania konfliktu nie jest pewny. Passus 2 Krn 14,8-15 co prawda podaje szczegó o inwazji niejakiego Zeracha, Kuszyty za panowania Asy, lecz w przekonaniu niektórych badaczy historyczności tego wydarzenia nie sposób dowieść, por. Pierwsza i Druga Księga Kronik, thum., wstęp i komentarz H. Langkammer, (Pismo Święte Starego i Nowego Testamentu w przektadzie z języków oryginalnych), Lublin 2001, s. 265. Tymczasem najazd Zeracha, jeśli uznać go za historyczny, mógł się dokonać za panowania faraona Osorkona I, syna Szeszonka (bibl. Sziszak), 
b) decyzja króla Judy o przekazaniu zawartości skarbca świątyni jerozolimskiej królowi Syrii w celu zyskania militarnego poparcia w jego walce z władcą Izraela (w. 18);

c) propozycja zawarcia przymierza poparta złożonym darem (w. 19);

d) decyzja zmiany partnera przymierza przez króla Syrii i atak na władcę Izraela (w. 20);

e) odstąpienie króla Izraela od ataku na Judę (w. 21).

Sens pierwszej linii w. 3 jest trudny do uchwycenia, jeśli próbuje się powiązać wezwanie do zawarcia przymierza z konkretnym momentem panowania Asy. Nie wiadomo, jak pojmować sformułowanie „między ojcem moim i ojcem twoim”. Może ono oznaczać: ,zawrzyj przymierze między mną i tobą (tak, jak trwało ono) między ojcem moim i ojcem twoim", co jednak nie jest nigdzie w księdze poświadczone. Może zatem ów zwrot oddawać sens kontynuowania niepisanej ugody władców, zapewniając po prostu spokój między oboma państwami. Teraz zaś Asa proponuje Ben-Hadadowi formalny pakt, przekupując go srebrem i złotem pochodzącymi z domu Bożego.

Niewątpliwie w wersecie chodzi o przymierze polityczno-militarne, nie religijne, niemniej autor tekstu greckiego opatrzył je zwrotem diatithèmi diathēkēn, tym samym, który widnieje w zakazach prawa Mojżeszowego. Manewr polityczny króla judzkiego miał wyraźnie na celu osłabienie zdolności militarnych północnego sąsiada, i dzięki temu umocnienie granicy północnej, aby ochronić Jerozolimę przed ewentualnymi atakami tego i kolejnych władców izraelskich ${ }^{17}$. Oczywiście z punktu widzenia polityki było to przedsięwzięcie ze wszech miar korzystne dla króla judzkiego, chociaż ogromną jego ceną było ogołocenie skarbca świątynnego z zawartości, którą wcześniej złożył król za czasów swego panowania (w. 15). Król syryjski posłuchał swego kontrahenta i zerwał układ z władcą izraelskim, atakując go i niszcząc przygraniczne tereny oraz miasta (w. 20). Ewidentnie każda ze stron zawartego paktu miała własne plany co do możliwych korzyści militarnych. Monarcha syryjski osłabił w ten sposób swego sąsiada, na co liczył także król judzki, który również mógł spodziewać się czasowego przynajmniej oddalenia niebezpieczeństwa zagrażającego właśnie ze strony Syrii, która wykrwawiła się w wojnie z Izraelem.

\footnotetext{
w przedziale lat 924-889 przed Chr., sam zaś negatywny bohater wydarzenia mógłby być którymś z dowódców armii egipskiej, może garnizonu stacjonującego przy Judei, w Gerarze, por. Y. Levin, The Chronicles of the Kings of Judah: 2 Chronicles 10-36: A New Translation and Commentary, London-New York 2017, s. 63. Inni badacze na podstawie zapisu 2 Krn 16,7 suponują lata 885-860 jako możliwy czas prorokowania nieznanego bliżej „widzącego” Chananiego, interweniującego u Asy po zawiązaniu przymierza z Ben-Hadadem, por. J.F. Nations, Profits of the Prophets: A Biblical Reference, Bloomington (IN) 2012, s. 13.

17 Por. P.R. House, 1, 2 Kings..., s. 197.
} 
Tymczasem właściwej oceny teologicznej posunięć politycznych Asy dokonał natchniony autor kronikarski, który zanotował interwencję proroka Chananiego u króla judzkiego, krytykującego go za to posunięcie (2 Par 16,7-9). Ukrytym motywem działań władcy był bowiem brak ufności Bogu i zastąpienie Jego gwarancji zaufaniem do człowieka, w dodatku poganina, na którego kosztowną łaskę ten się wydał. Dlatego prorok przypomniał królowi niedawną inwazję Zeracha, Kuszyty, którego armię Bóg pokonał na oczach króla, gdy ten zwrócił się do Niego o pomoc (2 Par 14,8-15). Właśnie tego zaufania zabrakło monarsze obecnie. Dowodem głupoty ze strony władcy judzkiego, wiążącego się z poganinem, a zarazem karą za odrzucenie Boga będą zatem walki z tymi samymi Syryjczykami, których wezwał obecnie na pomoc ${ }^{18}$, choć w sposób wyraźny ukaże się to dopiero wiek później w tzw. wojnie syro-efraimskiej, w 734 roku przed Chr. Odrzucony bowiem został Bóg, gwarantujący pokój darmowo, na mocy własnego zobowiązania ${ }^{19}$, wybrany zaś został ziemski władca pogański, któremu dodatkowo trzeba będzie zapłacić za niepewną ugodę.

Podsumowując całość opisywanego zdarzenia, należy zauważyć, że chociaż prawo Mojżeszowe nie jest ściśle przywołane, posunięcie króla rażąco sprzeciwia się istocie relacji Boga do Jego ludu. Zobowiązuje się On do udzielania konkretnej pomocy, lecz wymaga pełnego zaufania zarówno na mocy prawa, jak i pamięci o Jego interwencjach dla dobra narodu wybranego.

\section{4) przymierze Achaba $z$ Ben-Hadadem II}

Ugoda między królem izraelskim a syryjskim została zawarta na samym końcu pewnego ciągu zdarzeń o charakterze militarnym, będących skutkiem trwającego konfliktu między oboma państwami (3 Bas 21,1-34). Werset 34 oznajmia na samym końcu następującą treść:

i ustanowit z nim przymierze i odestat go wolno.

${ }^{18} \mathrm{~W}$ ten sposób objawia się teologiczna prawda, że ludzkie postępowanie nie jest $\mathrm{z}$ góry przesądzone. Sam człowiek wykuwa własny los, dokonując w teraźniejszości posunięć, które jednak będą miały wpływ na jego przyszłość. Bóg natomiast może zapowiedzieć te czy inne konsekwencje poczynań władców zwłaszcza w sferze wiary, choć również na płaszczyźnie politycznej czy militarnej. Konsekwencji tych nie można traktować jako Jego odpowiedzi na owe poczynania, lecz jako skutki postępowania samych zainteresowanych stron, por. D.S. Crowther, Prophets \& Prophecies of the Old Testament, Bountiful 1998, s. 89.

19 Por. m.in. Kpł 26,7-8; Pwt 28,7; Ps 89,23 oraz 1 Sm 7,3.10-11; 2 Sm 22,38-41; Joz 8,22; 2 Krn 20,22-25. 
Cały duży passus 3 Bas 21 można podzielić na następujące części:

a) inwazja Ben-Hadada na królestwo północne (w. 1);

b) poselstwo władcy syryjskiego do Achaba i targi między oboma królami (w. 2-11);

c) decyzja oblężenia Samarii (w. 12);

d) wyrocznia Boga dla Achaba (w. 13-15);

e) batalia obu władców i klęska Ben-Hadada (w. 16-21);

f) ponowna misja prorocka do Achaba (w. 22);

g) konsultacje u Ben-Hadada (w. 23-25);

h) druga wojna między oboma władcami i zwycięstwo Izraelitów (w. 26-30);

i) ułaskawienie dla króla syryjskiego (w. 31-34).

Ostatnia część opowiadania hagiografa obrazuje, jak pokonany, próbując zachować życie, wzbudzał litość w zwycięzcy, czemu miała służyć sceneria udawanego uniżenia przez nałożenie worów pokutnych i powrozów na szyję (w. 31). Wywołało to pożądany efekt przebaczenia najeźdźcom (w. 32) i pozwolenie ukazania się pokonanego przed zwycięzcą (w. 33), w rezultacie czego nastąpiło uwolnienie go i zawarcie przymierza (w. 34). Ceną uwolnienia był wpierw zwrot miast zagrabionych w poprzedniej kampanii ${ }^{20}$ oraz pozwolenie na prowadzenie handlu towarami izraelskimi w Damaszku ${ }^{21}$. Król Achab zgodził się na przedstawione mu propozycje i uwolnił Ben-Hadada, zawierając z nim przymierze. Trudno stwierdzić, czy miało ono charakter militarny, ponieważ obaj dotychczasowi adwersarze $\mathrm{w}$ jego wyniku prawdopodobnie nie zostali sprzymierzeńcami ${ }^{22}$. Sens diathêkē ukazuje się tu raczej jako prosty układ między nierównymi stronami, z których strona zwycięska zyskuje jakieś dobra, druga zyskuje także, przede wszystkim pokój, lecz po dokonaniu koniecznych ustępstw. Jest to typowe dla umów politycznych, zawieranych pod przymusem w wyniku przegranej walki ${ }^{23}$. Zapis biblijny kładzie jednak akcent na pewne gesty Achaba względem poko-

${ }^{20}$ Chodzi o miasta zajęte prawdopodobnie w wyniku wojny opisanej w $1 \mathrm{Krl} 15,18$-22, choć w opinii niektórych badaczy lista ta nie jest znana, co jedynie suponuje nowy przebieg granic między państwami, por. B. Mazar, Geshur and Maachah, JBL 80 (1961) 1, s. 16-28.

${ }^{21}$ Możliwe, że bazary handlowe były eksterytorialne, tzn. zwolnione z podatku na rzecz właściciela ziemi, na której dokonywały się transakcje, por. J.A. Montgomery, H.S. Gehman, A Critical and Exegetical Commentary: The Book of Kings, Edinburgh 1967, s. 325. Bardziej jednak chodzi o manifestację obecności izraelskiej na terytorium pokonanego wroga i kontrolę z bliska jego lojalności względem suwerena, por. V. Fritz, 1 \& 2 Kings..., s. 207.

${ }^{22}$ Niektórzy egzegeci są jednak zdania, że Achab liczył na wspólną koalicję z królem syryjskim przeciw wzrastającej potędze Asyrii, z którą do rozprawy doszło ostatecznie w bitwie pod Karkar za panowania Salmanassara III w roku 853 przed Chr., znanej z inskrypcji tzw. steli Salmanassara III, por. R.D. Patterson, H.J. Austel, 1,2 Kings, (Expositor's Bible Commentary, vol. 4: Kings-Job: with the New International Version of the Holy Bible), Grand Rapids 1988, s. 157.

${ }^{23}$ Przykładem układów skrajnie niekorzystnych dla strony przegranej jest pakt zawarty między zwycięskim faraonem Neko a pokonanym królem judzkim Joachazem w 2 Krl 23,33-34, zmuszo- 
nanego przeciwnika. Przyznaje mu równe prawa, pozwalając wstąpić na swój rydwan (w. 33). Tym samym publicznie okazuje mu przebaczenie, zobowiązując do lojalności, a gdy jego zwierzchnictwo zostanie uznane — do wierności postanowieniom umowy i zawarcia pokoju.

Właściwą ocenę tego postępowania króla izraelskiego ukazuje dopiero interwencja nieznanego proroka w w. $42 \mathrm{w}$ tym samym rozdziale księgi. Przemawia on w imieniu Boga, ostro krytykując decyzję darowania życia królowi syryjskiemu i uwolnienie go. Najważniejszy w poprawnym zrozumieniu relacji między Achabem a Ben-Hadadem jest tu hebrajski zwrot 'î̌s-hermî, „mąż mej klątwy”, czyli „człowiek przeklęty”, co Septuaginta przetłumaczyła jako anēr olethrion, „mąż śmierci”24. Źródłosłów hebrajski jest tu ważniejszy o tyle, że zawiera fundamentalny dla prawa Mojżeszowego termin hẹerem, „klątwa” w nakazie zniszczenia wszystkiego, co należy do wroga, łącznie z nim samym, o czym mówi omawiany wcześniej werset Pwt 7,25. Trudno jednak stwierdzić, czy hẹerem dotyczy tego właśnie zapisu, ponieważ w myśl Pwt 20,17 klątwa ta dotyczyła jedynie sześciu wybranych nacji, do których Aramejczycy — w wersji Septuaginty

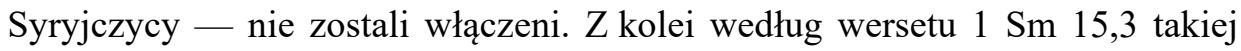
samej klątwie hẹerem podlegali Amalekici, przeznaczeni do całkowitego wytępienia, co oznacza, że wykaz narodów z Pwt 20,17 nie jest całkowity ani zamknięty. Dlatego właściwej, jak się wydaje, odpowiedzi trzeba szukać w 3 Bas 21,13 oraz 21,28, zamieszczających notę o wydaniu w ręce Izraelitów wojsk Ben-Hadada, co zapewniło Achabowi dwukrotne zwycięstwo. Taka decyzja Boga oznaczała jednak, że powinien on był zabić króla syryjskiego, ponieważ akt ów dopełniłby nad nim zwycięstwa. Darowanie mu życia oznaczało nie tylko zaprzepaszczenie okazji, by pozbyć się wroga, lecz przede wszystkim nieposłuszeństwo Bogu zapewniającemu owo zwycięstwo ${ }^{26}$. Stąd kara jest całkowicie zrozumiała: Achab własnym życiem zapłaci Bogu za życie swego nieprzyjaciela. Mimo więc że porozumienie między nimi nie wkracza ściśle w zakres obowiązującego prawa Mojżeszowego, Bóg zastrzega sobie możliwość karania za postępowanie niezgodne z Jego wolą.

nym do poddania się wszelkim nakazom króla Egiptu, łącznie z utratą tronu, por. P.R. House, 1,2 Kings..., s. 392-393.

${ }^{24}$ Zwrot ów można przetłumaczyć dwojako: w sensie czynnym jako ten, „który powoduje śmierć, zgubę, klęskę”, lub w sensie biernym: „mąż nędzny, nieszczęsny”, por. A. Bailly, Dictionnaire grec-français, Paris $1963^{26}$, s. 1366 .

${ }^{25}$ Por. także Lb 21,2-3; Pwt 2,34; 3,6; 13,16.18; 20,17; Joz 2,10 itd.

26 Por. P.R. House, 1, 2 Kings..., s. 230. 


\section{5) układ Achaza z Tiglat-pileserem III}

Zarówno passus 4 Bas 16,7-9, jak i 2 Par 28,16-21 relacjonują to wydarzenie, choć drugi z urywków dodaje własną ocenę całości przedsięwzięcia króla judzkiego, udającego się pod opiekę monarchy asyryjskiego w wojnie przeciw koalicji syryjsko-izraelskiej Resina i Pekacha, chcących zrzucić Achaza z tronu Judy, co rzeczywiście nastąpiło podczas tzw. wojny syro-efraimskiej w latach 734-732 przed $\mathrm{Chr}^{27}$. Krótka relacja Pierwszej Księgi Królewskiej została znacznie rozszerzona i zmodyfikowana w tradycji kronikarskiej. Do walk Achaza z Syryjczykami i Izraelitami (w. 5-8) zostały dodane liczne interwencje pomniejszych sąsiadów Judy (w. 17-18) wraz z ewaluacją teologiczną wydarzeń (w. 19). Na potrzeby poniższego omówienia wystarczy zacytować część materiału 4 Bas 16,7-9:

w. 7: Wystat Achaz postów do Taglathfalassara, króla Asyrii, mówiąc: stuga twoim i synem jestem.

w. 8: Przybądź i oswobodź mnie z ręki króla Syrii i z ręki króla Izraela, którzy zwrócili się przeciw mnie.

w. 9: Wziąt więc Achaz srebro i ztoto, które znalazt w skarbcach domu Bożego i domu królewskiego, i przestat królowi dary.

Budowa literacka fragmentu nie przedstawia trudności. Bliższy kontekst w. 5-9 opisuje:

a) obronę Jerozolimy przez Achaza przeciw wspólnej interwencji izraelsko-syryjskiej (w. 5-6), zwłaszcza przeciw Elath, na południu kraju (w. 5).

b) poselstwo do Asyrii i prośbę o interwencję, wzmocnioną łapówką (w. 7-8),

c) zgodę władcy imperium na atak przeciw koalicji Syrii i Izraela i kampanię zmierzającą do podporządkowania i likwidacji obu państw (w. 9a) ${ }^{28}$.

Na wstępie krótkiej analizy tekstu zauważyć trzeba, że nie zawiera on głównej prezentowanej konstrukcji gramatycznej diatithēmi diathēkē. Jej brak nie przesądza tymczasem o właściwym rozumieniu treści zapisu, zawierającego de facto pakt lub umowę między władcami. Na mocy tychże monarcha asyryjski zdecydował się interweniować w sprawie, o którą zabiegał u niego król Judy (4 Bas 16,9; 2 Par 28,20). Złoto i srebro, jako dary, pojawiły się już w przypadku zawarcia formalnego przymierza króla Asy z Ben-Hadadem I. Obecną umowę można traktować także jako układ suweren-wasal, przy czym ów drugi jest stroną działającą. Stąd właśnie wzmianka o darach służących przekonaniu do wejścia w nią

\footnotetext{
27 Por. tamże, s. 336.

${ }_{28}$ Por. B.O. Long, 2 Kings, FOTL 10, Grand Rapids 1991, s. 174.
} 
tego, od którego oczekiwał on pomocy. Teologicznego kolorytu debacie króla dodaje w tym czasie aktywność proroka Izajasza, radzącego władcy udanie się bezpośrednio pod opiekę Boga, wiernego przymierzu ze swym ludem i to aż tak dalece, że król Judy może prosić o znak od Boga dla siebie i poddanych w tej konkretnej sprawie (Iz 7,1-10). Odrzucenie oferty proroka powoduje wygłoszenie jednej z najsłynniejszych zapowiedzi mesjańskich (7,11-16), co jednak nie zmienia postawy władcy, nieposiadającego koniecznej siły wiary i zaufania do Boga.

Badania historyczne wykazują, że zwłaszcza formuła „sługi” i ,syna” jest znamieniem formalnych traktatów poddańczych, oznaczając pełną lojalność wobec pana ${ }^{29}$. Chodzi o zapis całkowitego uzależnienia, co jest tym bardziej godne napiętnowania, że król Judy czyni to z własnej woli, choć przymuszony okolicznościami politycznymi ${ }^{30}$. Także konieczność zapłacenia i wielkość stosownej daniny wynikają z warunków lub stanowią bezpośredni skutek traktatu politycznego ${ }^{31}$. Ocena postępowania Achaza, dokonana przez greckiego thumacza księgi, jest druzgocąca. W 2 Par 28,20 autor mówi o „uderzeniu” (epataksen) Tiglat-pilesera na Achaza. W kontekście wcześniejszego układu nie chodzi jednak o dosłowne wyrażenie walki, lecz o skutki polityki króla, które okazały się tak ciężkie jak sama walka między władcami. Może to również oznaczać, że mimo układu obaj monarchowie faktycznie nie zostali politycznymi przyjaciółmi, lecz władca asyryjski traktował króla Judy wyłącznie jako podporządkowanego sobie wasala. Werset 21 wspomina, że mimo wszelkich darów i kontrybucji dla monarchy asyryjskiego, w niczym mu to nie pomogło (ouk eis boètheian autō) najprawdopodobniej dlatego, że niebezpieczeństwo wydatków związanych z wojną przeciw swym wrogom zamienił na drugie, równie dla niego istotne, w postaci konieczności płacenia ogromnych sum pieniężnych z tytułu przyjęcia zależności od asyryjskiego suwerena.

Teologiczna ocena wydarzeń jest jednoznaczna: Achaz wybrał króla Asyrii, odnosząc do niego terminologię, jakiej autorzy biblijni używali w relacjach Izra-

29 Nazywanego wręcz „ojcem”, por. D. McCarthy, Notes on the Love of God in Deuteronomy and the Father-Son Relationship between Yahweh and Israel, CBQ 27 (1965), s. 144-147. Szerszy szkic problemu por. m.in. W. Moran, The Ancient Near Eastern Background of the Love of God in Deuteronomy, CBQ 25 (1963) 1, s. 77-87.

30 Por. J.B. Łach, Księgi 1-2 Królów..., s. 492.

31 Por. m.in. S. Moscati, The Face of the Ancient Orient: Near Eastern Civilization in Preclassical Times, Mineola 2001, s. 109, 179, 197. Płacenie łapówek było zabronione w Torze (Wj 23,8; Pwt 16,19), por. także R.L. Cohn, 2 Kings, (Berit Olam. Studies in Hebrew Narrative \& Poetry, ed. by D.W. Cotter), Collegeville 2000, s. 113. Należy podtrzymać opinię H. Tadmora i B. Cogana o ścisłym rozumieniu ,łapówki”, por. Ahaz and Tiglath-Pileser in the Book of Kings: Historiographic Considerations, Bib 60 (1979), s. 499-503. Autor Septuaginty rozumiał dar Achaza właśnie w tym negatywnym sensie korupcji politycznej, podobnie do wcześniejszego użycia terminu dōra w tym samym kontekście przekupstwa Asy wobec Ben-Hadada I w 3 Bas 15,19. 
el-Jahwe: „twój syn”, „twój sługa” oraz „wybaw”32. W ten właśnie sposób Jahwe został świadomie i dobrowolnie zastąpiony siłą człowieka, poganina, wybranego kosztem wiernego zawsze przymierzu Boga. Wydaje się, że tym razem układ polityczny nabrał szczególnego charakteru zdrady religijnej, dokonanej przez króla judzkiego. Jego religijnym skutkiem stanie się osłabienie wiary ludu, coraz bardziej przyzwyczajanego do odstępstw od wierności Bogu, którego można przecież zastąpić siłą człowieka. W taki właśnie sposób grecki autor Septuaginty zinterpretował później działania władcy judzkiego - jako wzrastające zagrożenie dla wiary ludu, postępującego na wzór własnego króla.

\section{6) pakt między Judą a Egiptem}

Historycznie został zawiązany za czasów króla judzkiego, Ezechiasza, w latach 705-701 przed Chr., gdy wzrosły nadzieje na uwolnienie się z mocnego uścisku imperium asyryjskiego po śmierci króla Sargona II, która nastąpiła w roku 705. Zarówno Egipt, jak i Juda były żywotnie zainteresowane osłabieniem imperium znad Tygrysu i Eufratu, świadome zagrożenia dla własnej niepodległości ${ }^{33}$. Zapis Iz 30,1-5 ukazuje prorocki punkt widzenia na politykę królestwa judzkiego końca VIII w. przed Chr.:

w. 1: Biada dzieciom odszczepieńczym, tak mówi Pan.

Wykonaliście wole, ale poza Mna, przymierze, ale nie wedlug ducha Mego, Dodajac nieprawość do nieprawości.

w. 2: Wyruszyli, by zejść do Egiptu, Mnie zaś nie zapytali, by skorzystać z pomocy od faraona i schronić się u Egipcjan,

w. 3: lecz poparcie faraona stanie się dla was wstydem a dla opierających się na Egipcie - hańba.

w. 4: ponieważ wasi zwierzchnicy przybyli do Tanis, zwiastuni niegodziwi na próżno będa zabiegać

w. 5: u ludu, który nie będzie im przydatny, ani dla pomocy, ani dla pożytku, lecz ku zawstydzeniu i pohańbieniu.

Także w tym tekście nie występuje explicite omawiana konstrukcja diatithēmi diathēkē. Komentatorzy jednak nie mają wątpliwości co do realnego układu mię-

\footnotetext{
${ }^{32} \mathrm{~W}$ odniesieniu do relacji Izraelita-Bóg Biblia notuje wręcz setki tych wyrażeń, których nie sposób tu wypisać wszystkich, por. M.J. De Jong, Isaiah Among The Ancient Near Eastern Prophets: A Comparative Study of the Earliest Stages of the Isaiah Tradition and the Neo-Assyrian Prophecies, Leiden-Boston 2007, s. 193-202.

${ }^{33}$ Szczegóły okoliczności historycznych tego czasu por. J. Nawrot, Zagłada Asyrii w teofanicznej symbolice ognia: Analiza tekstu Iz 30,27-33, Poznań 2000, s. 35-36, 37-39.
} 
dzy oboma państwami. Mocna w swej wymowie krytyka prorocka, czyniona w imieniu samego Boga, kieruje się przede wszystkim do decydentów polityki królestwa judzkiego: na pierwszym miejscu do króla, potem jego doradców, wreszcie do tych, którzy podjęli się wykonania misji zdobycia poparcia Egiptu w swym oporze przeciw monarchii asyryjskiej. Należy postawić jednak słuszne pytanie: czy atak proroka stanowi zarzut wobec aktywności politycznej w ogóle, czy tylko w tym konkretnym przypadku. Słusznie zauważają egzegeci, że brak jakiegokolwiek działania byłby wyrazem albo głębokiej wiary, albo skrajnej głupoty doradców Ezechiasza ${ }^{34}$. W ten sposób słowo Boże mogłoby stanowić podstawę politycznego kwietyzmu w każdej sytuacji zagrożenia i nieco łatwowiernego liczenia na ,pomoc z góry”. Prawdą jest, że kilka zwycięstw w bataliach polityczno-militarnych dokonało się w historii świata siłą samej modlitwy zainteresowanych stron ${ }^{35}$, lecz nie wydaje się to normalną drogą działania polityków odpowiedzialnych za bezpieczeństwo własnych narodów. Zawiązywanie aliansów polityczno-militarnych stało się wręcz standardem aktywności współczesnych przywódców państw ${ }^{36}$. W samej Biblii takie wyżej ukazane zbliżenia nie były za każdym razem atakowane same w sobie, lecz pod warunkiem, że służyły rzeczywistemu dobru narodu wybranego, czego przykładem są układy Abrahama z Abimelekiem lub Salomona z Chiramem. Z jakiego więc powodu zostały zaatakowane przez Izajasza próby koalicji judzko-egipskiej? Otóż — jak się wydaje - z dwóch zasadniczych:

a) nieinwazyjnej polityki faraona Szebitku, niezdolnego do przejęcia inicjatywy militarnej w koalicji państw opierających się imperium asyryjskiemu;

b) pominięcia Boga, jako rzeczywistego gwaranta pokoju w ziemi obiecanej ${ }^{37}$.

Posłowie judzcy musieli wiedzieć, że opieranie się na słabym Egipcie w istocie rzeczy nie pomoże w polepszeniu ich sytuacji. Samo zaś mocarstwo znad Nilu mogło jedynie wspierać koalicję małych państw regionu jako bufor przed atakiem Asyrii na własne terytorium. Nie liczyło się więc dla Egiptu rzeczywiste dobro układu politycznego z niewielkimi i słabymi królestwami Kanaanu, tylko własne bezpieczeństwo kosztem bezpieczeństwa koalicjantów. Stąd właśnie gorzkie słowa o zawstydzeniu i hańbie dla Judejczyków, pokładających próżne nadzieje na pomoc Egiptu (w. 3-5). Natomiast wyrzut w. 1-2 dotyczy drugiej z przyczyn polityki króla judzkiego, mianowicie pominięcia doradztwa proroka,

${ }^{34}$ Wypowiedzi innych badaczy cytuje m.in. T. Brzegowy, Księga Izajasza. Rozdziały 13-39, NKB.ST t. XXII/2, Częstochowa 2014, s. 557.

${ }^{35}$ Por. m.in. Wj 17,8-13; 2 Krn 20,14-24. Taką interpretację nadaje się również np. bitwie pod Lepanto, obronie Częstochowy podczas najazdu szwedzkiego, „,cudowi nad Wisłą” czy wycofaniu się Armii Czerwonej z Austrii po II wojnie światowej.

${ }^{36}$ Por. O. Kaiser, Isaiah 13-39: A Commentary, OTL, Philadelphia 1974, s. 286-287.

${ }^{37}$ Por. G.V. Smith, Isaiah 1-39: An Exegetical and Theological Exposition of Holy Scripture, NAC 15A, Nashville 2007, s. 511-512. 
który w imieniu Pana podałby właściwy kierunek działań, z pewnością inny niż ułuda współpracy z Egiptem, czego ostatecznie dowiodła cudowna interwencja Boga w obronie Jerozolimy w dalszym etapie konfliktu z Asyrią (Iz 37,33-35). Możność zawierania sojuszy politycznych nie pomniejsza tymczasem tego, że każde wierzące społeczeństwo powinno czuć się zobowiązane nadać swej wierze należną jej rolę także w sferze społecznej. Wiara bowiem nie jest jedynie jakimś ekscentrycznym dodatkiem do życia prywatnego, lecz — jak uczy dziś Kościół - rzeczywistością jak najbardziej realnie wpływającą na właściwy kierunek życia społecznego i politycznego na mocnym fundamencie moralnym. Tego właśnie ważnego odniesienia zabrakło Ezechiaszowi i prominentom królestwa Judy, podważającym przymierze, którego powinni czuć się stroną zobowiązaną do wierności. Zdecydowanie chodzi tu o przymierze synajskie, jedyne z trzech najważniejszych, które zobowiązywało do wierności pod karą anulowania go ${ }^{38}$, co silniej uwidacznia się w zastosowaniu terminologii związanej z kultem idolatrycznym. Sugeruje to nawet, że alians z Egiptem mógł zawierać bliżej nieznane elementy przejmowania kultu bałwochwalczego ${ }^{39}$. Stąd tak gwałtowna reakcja samego Boga, wyrażona ustami proroka. Zgodnie z późniejszą zapowiedzią Jr 6,19 król, jego doradcy i cała społeczność zbiorą owoce własnych pomysłów, odrzucenia słów Pana i złamania Jego praw.

\section{7) uklad między Sedecjaszem a Nabuchodonozorem}

Przedostatni z serii konkretnych przykładów umów międzypaństwowych podaje tekst Ez 17,13, ukazujący prorocką ocenę ostatnich momentów niepodległego bytu królestwa judzkiego, tuż przed zniszczeniem Jerozolimy w roku 587 przed Chr. Bliższy kontekst w. 11-18 nakreśla sytuację od przełomu lat 598 i 597, gdy król babiloński po raz pierwszy najechał Judę i wziął do niewoli Joakima, ostatniego z potomków dynastii dawidowej po trzymiesięcznym jego panowaniu wraz z jego rodziną, całym dworem, znaczniejszymi poddanymi i wykształconymi warstwami społecznymi, plądrując przy tym świątynię i pałac królewski, niszcząc dom Boży i miasto (4 Bas 24,10-14) ${ }^{40}$. Ustanowił królem na miejsce Joakima jego stryja, Mattaniasza, któremu zmienił imię na Sedecjasz, a który w głupocie swego postępowania zbuntował się przeciw Nabuchodonozorowi (2 Krl 24,17-20). Odnośny werset w Księdze Ezechiela zamieszcza następujące stwierdzenie:

${ }^{38}$ Szczególnie wyraźnie akcentuje to tekst Kpł 26,14-15, łączący motyw nieposłuszeństwa ze złamaniem przymierza. Por. też Lb 15,30-31; 2 Krl 17,15; 2 Krn 36,16; Ez 16,59; Za 7,11-13.

${ }^{39}$ Por. J. Vermeylen, Du prophète Isaïe à l'apocalyptique: Isaïe I-XXXIV, miroir d'un demi-millénaire d'expérience religieuse en Israël, Paris 1977, s. 408-410.

${ }^{40}$ Por. J. Warzecha, Historia dawnego Izraela, Warszawa 2005, s. 338-339. 
Zabierze z nasienia królestwa, ustanowi z nim przymierze,

zobowiąże go przysięga i zabierze przywódców ziemi.

Czas przyszły całej wypowiedzi został zastosowany w wersji greckiej tekstu prorockiego jako zapowiedź słowa, jakie dotarło do proroka, by objawić mu niedaleką przyszłość. Wersety 11-18 stanowią wyjaśnienie Boże wcześniejszej alegorii o dwóch orłach i wierzchołku cedru (w. 1-10). W myśl słowa (w. 1) władca babiloński najedzie kraj i pozbawi go króla oraz starszyzny (w. 12). W jego miejsce ustanowi nowego króla i zawrze z nim przymierze, do którego zachowania zobowiązał cały osłabiony kraj (w. 14). Następca jednak zbuntuje się przeciw niemu, będzie spiskował z Egiptem (w. 15a) ${ }^{41}$, co jednak z woli Bożej nie doprowadzi do uwolnienia się od zwierzchnictwa babilońskiego (w. 15b). Za złamanie przymierza z Bogiem król zostanie ukarany i umrze na wygnaniu w Babilonie (w. 16), ponieważ spodziewana z Egiptu pomoc nie nadejdzie, a rozgniewany monarcha babiloński ponownie otoczy Jerozolimę, zabijając wielu obrońców (w. 17). Wybierając faraona zamiast Boga, Sedecjasz doprowadzi siebie do wygnania i śmierci, a kraj do ostatecznego upadku (w. 18) ${ }^{42}$.

Ukazany kontekst jednoznacznie wskazuje na wymuszenie traktatu przez zwycięzcę na pokonanym, czyli narzucenie warunków prowadzących do całkowitego uzależnienia politycznego i militarnego Judy od Babilonii. Zwrot diathēsetai pros auton diathēkēn w w. 13 ogranicza się więc wyłącznie do umowy politycznej, nie zaś obopólnego przymierza, i nie funkcjonuje na poziomie religijnym. Nic bowiem nie wskazuje na zmuszenie pokonanego króla Judy do przyjęcia wiary pogańskiej i konieczności uprawiania bałwochwalstwa. Natomiast wagę, jaką król babiloński przykładał do trwałości paktu, ukazuje wzmocnienie układu przysięgą ze strony marionetkowego władcy judzkiego (eisaksei auton en ara) ${ }^{43}$. Nie jest ona traktowana jako dodatek do traktatu, lecz jako jego składowa część, po której zawierano układ w sposób rytualny ${ }^{44}$.

Ważne wydaje się tu jednak poprawne zdefiniowanie tezy hagiografa, że układ Sedecjasza z faraonem stanowi jednoczesne złamanie przymierza z Bogiem (w. 15-16). Nasuwa się bowiem pytanie, czy Sedecjasz naruszył przymierze

${ }^{41}$ Tajemny układ z faraonem Chofrą miał doprowadzić do przybycia wojsk egipskich i walki z Babilończykami, por. A.S. Jasiński, Komentarz do Księgi proroka Ezechiela. Rozdziały 21-30, OBT 111, Opole 2013, s. 180.

${ }^{42}$ Bardziej szczegółowy podział perykopy por. R.M. Hals, Ezekiel, FOTL 19, Grand Rapids 1989, s. 113.

${ }^{43}$ Hebrajski odpowiednik 'ālâ oznacza przekleństwo, jakie spada na tego, kto je wypowiada, a zarazem nie dotrzymuje danego słowa, por. L.C. Allen, Ezekiel 1-19, WBC 28, Dallas 1994, s. 256.

${ }_{44}$ Poprzez przyzywanie bóstw na świadków, por. D.I. Block, The Book of Ezekiel. Chapters 1-24, NICOT, Grand Rapids-Cambridge 1997, s. 542. 
Boga dopiero wówczas, gdy jako gwaranta niezależności swego państwa wybrał faraona zamiast Boga. Wydaje się, że uczynił to znacznie wcześniej, gdyż tekst 4 Bas 24,19-20 ogólnie akcentuje jego poczynania jako „złe w oczach Pana”, bunt zaś przeciw Nabuchodonozorowi jako efekt gniewu Boga przeciw niemu i Judzie. Bunt ten wyraża osobistą głupotę Sedecjasza jako karę za błędne postępowanie, czyli odrzucenie wcześniejszej zachęty Jeremiasza do dobrowolnego poddania się pod władzę króla babilońskiego (Ier 45,17-18). Jeśli obecnie został przyzwany także Bóg Izraela, to Sedecjasz uczynił również Jego gwarantem swej lojalności wobec monarchy babilońskiego, o czym wprost wspomina werset 2 Par 36,13. Złamanie przysięgi oznacza więc uczynienie z Jahwe Boga kłamliwego lub tolerującego niegodziwe postępowanie poddanego wobec suwerena ${ }^{45}$. To jest właśnie główna konsekwencja całego układu, która dopiero ma nastąpić: przysięga złożona królowi babilońskiemu z przyzywaniem Boga czyni z Niego gwaranta rzekomej prawdziwości intencji oraz dotrzymania zobowiązań. Autorytet Boga wystawiony więc został na szwank. Dlatego właśnie plany Sedecjasza związane z Egiptem spełzną na niczym ${ }^{46}$.

\section{8) układ Jonatana z Demetriuszem $I^{47}$}

Ostatni z proponowanych tekstów znajduje się w 1 Mch 10,26, przenosząc czytelnika na poziom dyplomacji królewskiej:

\section{Ponieważ zachowaliście z nami układy i pozostajecie w naszej przyjaźni i nie ustapiliście naszym wrogom, ustyszeliśmy i wyrażamy radość.}

Wersety $22-46 \mathrm{w}$ rozdziale $10 \mathrm{księgi,} \mathrm{w} \mathrm{przeciwieństwie} \mathrm{do} \mathrm{wszystkich} \mathrm{pozosta-}$ łych, zawierają wręcz śladowy tekst relacji historycznej hagiografa, stanowiącej tu jedynie obramowanie w formie wstępu i zakończenia całej treści środkowej (w. 22.25a.-46.47). Natomiast pozostałą całość podzielić znów można na dwie, bardzo nierówne części: wypowiedź króla seleuckiego (w. 23-24) oraz cytowaną treść dokumentu monarchy skierowanego do Jonatana (w. 25-45). Z dwóch bohaterów passusu król seleucki absolutnie dominuje (w. 22-45), a reakcja Jonatana i reszty powstańców wprowadzona zostaje dopiero w w. 45-46.

45 Por. L.E. Cooper Sr., Ezekiel: An Exegetical and Theological Exposition of Holy Scripture, NAC 17, Nashville 1994, s. 182.

46 Por. M. Greenberg, Ezekiel 1-20: A New Translation with Introduction and Commentary, AB 22, Garden City 1983, s. 321.

47 Polityczny układ Jonatana z władcą pogańskim został zamieszczony w tej części omówienia, ponieważ nie wchodzi w zakres tekstu, jakiemu nada brzmienie część trzecia, ograniczająca się ściśle do przymierza z republiką rzymską. 
Na samym początku listu monarcha podkreśla wierność tej części, a dzięki obecnym przywilejom pragnie wynagrodzić im dotychczasowe uciążliwości. Wyrażana radość Demetriusza I z rzekomej wierności Żydów postanowieniom paktu ma świadczyć o tym, że król uznaje lojalność wodza i pragnie dalej spieszyć ze swymi dobrodziejstwami.

Czasownik syntēereo, „strzegę, przestrzegam, zachowuję”, odwołuje zapewne do oczekiwań króla, że zostanie potraktowany na zasadzie wierności i uczciwości, jaką pobożny Żyd spełnia wobec swego Boga na wzór Abrahama, który respektował w całości prawo Boże ${ }^{48}$. Jednak dla Jonatana, jako Żyda, najważniejszą wskazówką powinno być dochowanie wierności umowie tylko z człowiekiem pobożnym, strzegącym przykazań Bożych ${ }^{49}$. Charakteryzuje to człowieka religijnego, nie zaś poganina, $\mathrm{z}$ definicji traktującego wszelkie układy bardzo narzędziowo, co mogłoby się skończyć kolejnym ciężkim rozczarowaniem religijnego Żyda ${ }^{50}$. Podobne ostrzeżenie zawiera rzeczownik synthēkē, ,układ, pakt”, użyty w nazwaniu rzeczonego sojuszu. Otóż w Iz 30,1 prorok zarzuca ówczesnym dyrygentom polityki królestwa judzkiego wiązanie się paktami (synthēkai) z Egiptem, lecz nie za aprobatą Boga, za co przyjdzie im zapłacić słono, ponieważ takie układy nie będą im w niczym przydatne a wręcz szkodliwe, z racji czego srodze się na nich zawiodą ${ }^{51}$. Tę samą naukę ma wynieść obecnie Jonatan w razie związania się równie szkodliwym traktatem z Demetriuszem.

Podobny ton ostrzeżenia, a także zachęty, kryje w sobie kolejny czasownik emmenō, „pozostaję wierny, trzymam się, jestem posłuszny”. Otóż w świetle prawa izraelskiego przeklęty jest ten, kto nie trzyma się wiernie wszystkiego, co nakazał Bóg, tzn. całości prawa wyrażonego w Torze ${ }^{52}$. Skoro Demetriusz starał się to prawo tępić zbrojnie i okrutnie, wiązanie się z nim obecnie byłoby zdradą prawa, a zatem mogłoby podpadać pod przekleństwo. Żaden plan podejmowany bez Boga nie przetrwa ${ }^{53}$. Przedłużanie koalicji z Demetriuszem stanie się tak samo zgubne, jak postępowanie mieszkańców Jerozolimy chcących do końca trwać przy swym królu, mimo że ten dawno utracił już Boże wspomożenie, opisane W wersecie Jr 21, $9^{54}$.

${ }^{48}$ Por. Syr 44,20; por. 41,14; Tb 1,11; 3,15.

${ }^{49}$ Ten sam termin syntêreō można odnaleźć także w wersecie Syr 37,12.

${ }^{50}$ O czym przekonuje cytat Prz 15,4 w swej greckiej wersji, por. La Bible d'Alexandrie: Les Proverbes, t. 17, trad., éd. D.M. d'Hamonville, Paris 2000, s. 247-248.

${ }^{51}$ Podobnie do Iz 30,3, por. J. Nawrot, Zagłada Asyrii..., s. 37-42.

52 Co dobrze naświetla werset Pwt 27,26, w którym można odnaleźć konstrukcję ouk emmenei, por. D.L. Christensen, Deuteronomy 21:10-34:12, WBC 6B, Dallas 2002, s. 663.

${ }_{53}$ Odpowiedni tu werset Iz 8,10 zawiera podobny zwrot ou mē emmeine, por. G.V. Smith, Isaiah 1-39 ..., s. 224-225. Odwrotnie, zgodnie z tradycją mądrościową kto enemeinen (,wytrwał”) w bojaźni Pańskiej, ma zagwarantowaną Jego stałą opiekę, o czym przekonują wersety Syr 2,10 i Iz 30,18.

${ }^{54}$ Por. P.C. Craigie et al., Jeremiah 1-25, WBC 26, Dallas 1991, s. 289. 
W drugiej linii w. 26 monarcha wyraża radość z otrzymania wiadomości o rzekomej wierności powstańców panującej dynastii. Autor biblijny nawiązuje tym stwierdzeniem do wersetu Lm 1,21, gdzie autor żali się na postawę wrogów Izraela, którzy cieszą się, gdy usłyszeli o jego upadku ${ }^{55}$. W taki sam sposób wierność powstańców królowi może się okazać dla niego radością, dla nich zaś sposobnością do upadku. Wszystkie te odniesienia biblijne składają się na mocny teologiczny fundament odmowy Jonatana dalszego uznawania Demetriusza jako sprzymierzeńca. Mają też usprawiedliwić Jonatana w jego decyzji sojuszu z Aleksandrem mimo początkowego wykorzystania listów panującego władcy do zwiększenia frontu oporu przeciw monarchii seleuckiej.

\section{Podsumowanie}

Dokonana egzegeza poszczególnych wersetów Septuaginty wskazuje na to, że dwa pierwsze przymierza zawarte między przedstawicielem narodu wybranego a stroną pogańską (Abraham i Salomon) nie naruszyły zobowiązań wynikających z prawa Mojżeszowego. Teologiczny portret Abrahama w Księdze Rodzaju pozwala jednoznacznie ocenić jego postępowanie w świetle nakazów prawa, chociaż formalnie pojawiły się one znacznie później, bo za czasów Mojżesza. Na podobną ocenę zasługuje pakt między Salomonem a Chiramem. Natomiast późniejsze przymierza królów Izraela i Judy z władcami pogańskimi należy ocenić jednoznacznie negatywnie. Same w sobie nie stanowiły wprawdzie formalnego przekroczenia zakazów Mojżeszowych, jednak zostały ocenione jako zamach na zaufanie do Boga, jedynego Partnera przymierza między Nim a Izraelitami. Taka interpretacja jest możliwa zwłaszcza w świetle tekstu Pwt 7,6, w którym zaakcentowana została wyjątkowość Izraela z racji jego wyboru przez Boga spośród wszystkich ludów ziemi. Ponieważ zaś dokonało się to na fundamencie zawartego pod Synajem przymierza, posiada ono dla Izraela charakter układu jedynego w swoim rodzaju, którego nie powinien zastępować żaden inny, zawierany z człowiekiem, tym bardziej poganinem. W każdym z powyższych przypadków - począwszy od króla Asy, na arcykapłanie Jonatanie skończywszy — nastąpiło faktyczne naruszenie zasady Boga jako jedynego Partnera przymierza z Jego ludem. $Z$ tej właśnie racji każdy z tych układów spotkał się z uzasadnioną krytyką już to któregoś z proroków, już to samego autora natchnionego. Trudno wprawdzie mówić o naruszeniu istoty wiary Izraela w wyniku nawiązanych relacji dyplomatycznych, lecz z pewnością naruszona została zasada jedyności Boga jako fundamentu wszelkich płaszczyzn życia Jego ludu, w tym także płaszczyzny

${ }^{55}$ Ten sam zwrot èkousan... kai echarēsan, por. F.B. Huey, Jeremiah - Lamentations: An Exegetical and Theological Exposition of Holy Scripture, NAC 16, Nashville 1993, s. 457-458. 
politycznej, która nie powinna zostać wyłączona z zakresu wiary narodu wybranego.

\section{Alliances between Israel and Other Nations in Light of the Pentateuch's Prohibitions in the Greek Bible}

\section{Summary}

The conducted exegesis of some particular verses from the Septuagint indicates that two initial covenants made between a representative of the chosen nation with a Gentile party (Abraham and Solomon) did not breach the obligations resulting from the Law of Moses. The theological portrait of Abraham in the Book of Genesis captures an unambiguous evaluation of his conduct in accordance with the Law although the Law itself appeared considerably later when Moses lived. The pact between Solomon and Hiram deserves a similar evaluation. However, the later covenants between the kings of Israel and Judah with Gentile rulers deserve an extremely negative evaluation. Although they did not formally violate the Mosaic prohibitions, they were evaluated as a violation of trust in the Lord as He was the only Partner of the covenant between Himself and the Israelites. Such an interpretation is possible especially in light of Deut 7:6 which accentuates the uniqueness of Israel as a nation chosen by God from among other nations. And because this selection of Israel was done on the foundation of the covenant made on the Mount Sinai, it should be a one-of-a-kind covenant that should not be replaced with another pact signed with a human being, and let alone a Gentile. In all of the cases above, starting from King Asa and ending with Archpriest Jonathan, there was a true violation of the rule whereby the Lord was the only Partner of the covenant with His people. Thus, each of the analyzed treatises met with valid criticism both from a prophet and the inspired author. It is difficult to treat these violations as a major breach of the faith of Israel because of the established diplomatic relations. However, it was the rule of God's uniqueness as a foundation for any sphere in the life of the chosen people that was violated. It included the political sphere which should not be excluded from the chosen people's faith.

\section{Keywords}

Old Testament, Septuagint, the First Book of Maccabees, exegesis, covenants

\section{Słowa kluczowe}

Stary Testament, Septuaginta, Pierwsza Księga Machabejska, egzegeza, przymierza 


\section{Skróty}

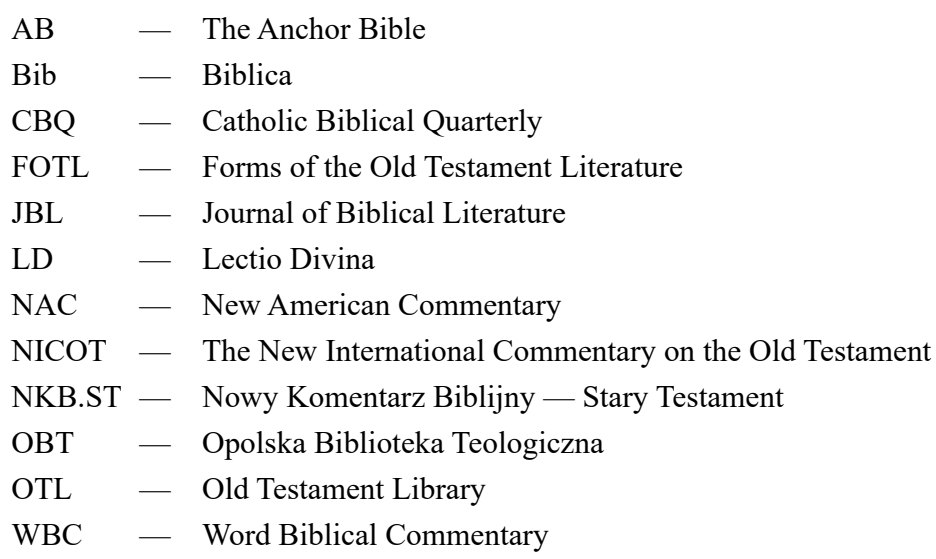

\section{Bibliografia}

Allen L.C., Ezekiel 1-19, WBC 28, Dallas 1994.

Bailly A., Dictionnaire grec-français, Paris $1963^{26}$.

Block D.I., The Book of Ezekiel: Chapters 1-24, NICOT, Grand Rapids-Cambridge 1997.

Brzegowy T., Księga Izajasza. Rozdziały 13-39, NKB.ST t. XXII/2, Częstochowa 2014.

Cazeaux J., Le partage de minuit. Essai sur la Genèse, LD, Paris 2006.

Christensen D.L., Deuteronomy 21:10-34:12, WBC 6B, Dallas 2002.

Coats G.W., Genesis: with an Introduction to Narrative Literature, FOTL 1, Grand Rapids 1983.

Cohn R.L., 2 Kings, (Berit Olam: Studies in Hebrew Narrative \& Poetry, ed. by D.W. Cotter), Collegeville 2000.

Cooper L.E., Sr., Ezekiel: An Exegetical and Theological Exposition of Holy Scripture, NAC 17, Nashville 1994.

Craigie P.C. et al., Jeremiah 1-25, WBC 26, Dallas 1991.

Crowther D.S., Prophets \& Prophecies of the Old Testament, Bountiful 1998.

De Jong M.J., Isaiah Among the Ancient Near Eastern Prophets: A Comparative Study of the Earliest Stages of the Isaiah Tradition and the Neo-Assyrian Prophecies, Leiden-Boston 2007.

Fritz V., 1 \& 2 Kings. A Continental Commentary, Minneapolis 2003.

Greenberg M., Ezekiel 1-20: A New Translation with Introduction and Commentary, AB 22, Garden City 1983.

Hals R.M., Ezekiel, FOTL 19, Grand Rapids 1989.

Hamilton V.P., The Book of Genesis, Chapters 1-17, NICOT, Grand Rapids 1990.

House P.R., 1, 2 Kings: An Exegetical and Theological Exposition of Holy Scripture, NAC 8, Nashville 1995. 
Huey F.B., Jeremiah - Lamentations: An Exegetical and Theological Exposition of Holy Scripture, NAC 16, Nashville 1993.

Jasiński A.S., Komentarz do Księgi proroka Ezechiela. Rozdziały 21-30, OBT 111, Opole 2013.

Kaiser O., Isaiah 13-39: A Commentary, OTL, Philadelphia 1974.

Krauss H., Küchler M., Erzählungen der Bibel II: Das Buch Genesis in literarischer Perspektive. Abraham - Isaak - Jakob, Göttingen 2004.

La Bible d'Alexandrie: Les Proverbes, t. 17, trad., éd. D.M. d'Hamonville, Paris 2000.

Lemański J., Księga Rodzaju, rozdziały 11,27-36,43. Wstęp - przekład z oryginału komentarz, NKB.ST, t. I/2, Częstochowa 2014.

Levin Y., The Chronicles of the Kings of Judah: 2 Chronicles 10-36: A New Translation and Commentary, London-New York 2017.

Long B.O., 2 Kings, FOTL 10, Grand Rapids 1991.

Łach J.B., Księgi 1-2 Królów. Wstęp - przekład z oryginału - komentarz - ekskursy, (Pismo Święte Starego Testamentu, seria KUL, t. 4, cz. 2), Poznań 2007.

Mazar B., Geshur and Maachah, JBL 80 (1961) 1, s. 16-28.

McCarthy D., Notes on the Love of God in Deuteronomy and the Father-Son Relationship between Yahweh and Israel, CBQ 27 (1965), s. 144-147.

Montgomery J.A., Gehman H.S., A Critical and Exegetical Commentary: The Book of Kings, Edinburgh 1967.

Moran W., The Ancient Near Eastern Background of the Love of God in Deuteronomy, CBQ 25 (1963) 1, s. 77-87.

Moscati S., The Face of the Ancient Orient: Near Eastern Civilization in Pre-classical Times, Mineola 2001.

Nations J.F., Profits of the Prophets: A Biblical Reference, Bloomington (IN) 2012.

Nawrot J., Izrael wobec zakazu sprzymierzania się z poganami w wybranych tekstach Septuaginty: część I, „Poznańskie Studia Teologiczne” 34 (2019), s. 7-28.

Nawrot J., Zagłada Asyrii w teofanicznej symbolice ognia: Analiza tekstu Iz 30,27-33, Poznań 2000.

Patterson R.D., Austel H.J., 1,2 Kings, (Expositor's Bible Commentary, vol. 4: KingsJob: with the New International Version of the Holy Bible), Grand Rapids 1988.

Peterson B.N., Genesis as Torah: Reading Narrative as Legal Instruction, Eugene 2018.

Pierwsza i Druga Księga Kronik, tłum., wstęp i komentarz H. Langkammer, (Pismo Święte Starego i Nowego Testamentu w przekładzie z języków oryginalnych), Lublin 2001.

Sailhamer J.H., The Meaning of the Pentateuch: Revelation, Composition and Interpretation, Downers Grove 2009.

Smith G.V., Isaiah 1-39: An Exegetical and Theological Exposition of Holy Scripture, NAC 15A, Nashville 2007.

Sweeney M.A., I \& II Kings: A Commentary, OTL, Louisville 2013.

Tadmor H., Cogan B., Achaz and Tiglath-Pileser in the Book of Kings: Historiographic Considerations, Bib 60 (1979), s. 499-503. 
Vermeylen J., Du prophète Isaïe à l'apocalyptique: Isaïe I-XXXIV, miroir d'un demi-millénaire d'expérience religieuse en Israël, Paris 1977.

Warzecha J., Historia dawnego Izraela, Warszawa 2005.

Whybray R.N., Genesis [w:] The Oxford Bible Commentary, ed. by J. Barton, J. Muddiman, Oxford 2001, s. 38-66. 